ROCZNIKI TEOLOGICZNE

Tom LXVII, zeszyt $9-2020$

DOI: http://dx.doi.org/10.18290/rt20679-9

ZDZISŁAW KUPISIŃSKI SVD

\title{
ŚRODA POPIELCOWA W LITURGII KOŚCIOŁA I OBRZĘDOWOŚCI LUDOWEJ TRADYCJA A WSPÓŁCZESNOŚĆ
}

\author{
ASH WEDNESDAY IN CHURCH LITURGY AND FOLK RITUALS \\ TRADITION AND MODERNITY
}

\begin{abstract}
The aim of the article is to present Ash Wednesday in the liturgy of the Church and to analyze the way of how this day is experienced in the tradition and folk piety, with particular emphasis on customs and rituals. The author makes a reference to the Church's documents and draws attention to the values that result from the integration of two forms of worship, i. e. liturgy and folk piety. The author drew on the literature on the subject, as well as his stationary ethnographic fieldwork on annual (1990-1994) and funeral rituals (1997-2006) conducted in the Opoczno and Radom subregions. In recent years he also used the method of participant observation.

The article is divided into two parts. In the first one the author recalls the genesis of the Ash Wednesday liturgy and the history of religious rituals performed on that occasion; further he discusses the symbolism of ashes, focusing mainly on the customs that once prevailed in the Polish countryside, namely participation in the liturgy, characteristic fasting meals and penitential clothing. The second part of the study presents Ash Wednesday as the cut-off date between the carnival and Lent period; in the past it was a day of practicing folk rituals of an entertaining nature (e.g. dragging an "Ash Wednesday log" or a "women's comber - fun"). Many of these customs evoked old pre-Christian Spring rituals, and their practice was for utilitarian gains. The author shows the changes that had taken and are still taking place in Polish society in the perception of the first day of Lent. Moreover, he emphasizes the disappearance of many once popular ceremonies and rituals, highlighting at the same time the relevance and durability of the custom of putting ashes on heads, which still best reflects the meaning of Ash Wednesday.
\end{abstract}

Key words: ash; Ash Wednesday; penitential practices; fasting; folk piety.

Dr hab. ZDZISŁAW KUPISIŃSKI SVD - Katedra Religiologii i Misjologii w Instytucie Nauk Teologicznych Katolickiego Uniwersytetu Lubelskiego Jana Pawła II; e-mail: dzidek@kul.lublin.pl; ORCID: https://orcid.org/0000-0003-4775-278X. 
Kalendarz liturgiczny Kościoła katolickiego odsłania misterium Chrystusa, począwszy od tajemnicy Wcielenia i Narodzenia, aż do Wniebowstąpienia i Zesłania Ducha Świętego oraz oczekiwania błogosławionej nadziei i przyjścia Pańskiego ${ }^{1}$. Rok liturgiczny rozpoczyna się w pierwszą niedzielę Adwentu, a kończy - tydzień po niedzieli Chrystusa Króla. Posiada własną strukturę, podziały i święta. Środa Popielcowa rozpoczyna okres Wielkiego Postu, a jej data jest zależna od terminu uroczystości Zmartwychwstania Pańskiego, czyli pierwszej wiosennej pełni księżyca.

Religijność ludowa, charakterystyczna dla mieszkańców wsi, różniła się od instytucjonalnej, jednak w zasadniczych kwestiach zgodna była z nauką Kościoła. Religijność ta ściśle łączyła się z pobożnością ludową. O ile religijność oznaczała związek i życie z Bogiem, o tyle pobożność wyrażała wolę oddania się Bogu, a wypływała z gorliwości i zapału modlącego się czło wieka. Pobożność stawała się źródłem rodzących się wewnętrznych aktów człowieka, w których wierzący okazuje cześć i zaufanie Bogu. Te wewnętrzne przeżycia pragnie zamanifestować, a wolę oddania się Bogu wyrazić za pomocą słów i gestów ${ }^{2}$.

Na wartości płynące z połączenia liturgii i pobożności ludowej zwraca uwagę Kongregacja ds. Kultu Bożego i Dyscypliny Sakramentów:

Liturgia i pobożność ludowa są dwiema formami kultu i powinny pozostawać we wzajemnej i owocnej relacji; w każdym przypadku liturgia musi stanowić punkt odniesienia, żeby wyraźnie i z roztropnością «ukierunkować ducha modlitwy i życia charyzmatycznego» przejawiającego się w pobożności ludowej. Pobożność ludowa natomiast, ze swymi symbolicznymi i wyrazistymi wartościami, może przyczynić się do skutecznej inkulturacji liturgii i pozytywnie wpływać na jej twórczy dynamizm $^{3}$.

Jan Paweł II zwraca uwagę na znaczenie pobożności ludowej w rozwoju życia religijnego i potrzebę włączenia ludowych form pobożności do katechezy:

Mam tu na myśli pewne formy pobożności, które w wielu stronach lud wierny zachowuje ze wzruszającą żarliwością i czystą intencją, chociaż wiara leżąca u ich

\footnotetext{
1 „Konstytucja o Liturgii Świętej 'Sacrosanctum Concilium”, w Sobór Watykański II, Konstytucje, dekrety, deklaracje (Poznań: Pallottinum, 2002), nr 102.

${ }^{2}$ Aniela DyLus, „Pobożność”, w Stownik teologiczny, red. Andrzej Zuberbier (Katowice: Księgarnia św. Jacka, 1998), 417-418; Jerzy SkotNICKI, „Pobożność”, w Katolicyzm A-Z, red. Zbigniew Pawlak (Poznań: Księgarnia św. Wojciecha, 1982), 307-308; Zdzisław KuPISIŃSKI, Adwent i Boże Narodzenie w regionie opoczyńskim. Studium religijności ludowej (Warszawa: Verbinum, 1997), 5-7.

${ }^{3}$ Kongregacja DS. Kultu Bożego i Dyscypliny Sakramentów, Dyrektorium o pobożności ludowej i liturgii. Zasady i wskazania (Poznań: Pallottinum, 2003), nr 58.
} 
podłoża wymaga oczyszczenia, czy nawet pewnego sprostowania pod wielu względami. Przypominają się tu niektóre łatwe do zrozumienia modlitwy, tak chętnie powtarzane przez wielu prostych ludzi, czy pewne formy pobożności, praktykowane ze szczerym pragnieniem pokutowania lub przypodobania się Bogu ${ }^{4}$.

Natomiast w liście na 25-lecie Konstytucji o liturgii papież w trosce o rozwój liturgii pisał:

[...] należy koniecznie zwrócić uwagę na pobożność ludową chrześcijan i na jej stosunek do życia liturgicznego. Nie można owej pobożności ludowej lekceważyć ani traktować jej z obojętnością czy pogardą, jest ona bowiem bogata w różnorakie wartości i już sama w sobie wyraża religijne nastawienie wobec Boga. Jednak pobożność ta stale potrzebuje ewangelizacji, aby wiara, którą wyraża, stawała się wciąż bardziej dojrzała i autentyczna. Zarówno rozmaite nabożeństwa ludu chrześcijańskiego, jak też inne formy pobożności są pożądane i godne zalecenia, pod warunkiem, że nie będą zastępowały ani nie będą mieszane z nabożeństwami liturgicznymi. Autentyczne duszpasterstwo liturgiczne potrafi się oprzeć na bogactwie ludowej pobożności, oczyszczać ją i poprowadzić ku Liturgii, jako dar ofiarny różnych narodów ${ }^{5}$.

Autor artykułu podejmuje próbę prezentacji i analizy przeżywania Środy Popielcowej w liturgii Kościoła katolickiego ze szczególnym uwzględnieniem

\footnotetext{
${ }^{4}$ JAN PAWE⿺ II, „Adhortacja apostolska 'Catechesi tradendae”, w Adhortacje apostolskie Ojca Świętego Jana Pawła II (Kraków: Wydawnictwo Znak, 1996), nr 54.

5 JAN PAWEE II, „List apostolski 'Vicesimus quintus annus' z okazji XXV rocznicy ogłoszenia Konstytucji Soborowej o Liturgii Świętej (04.12.1988)”, w Wybór listów Ojca Świętego Jana Pawła II, t. 2, red. Piotr Słabek, Jacek Jękot (Kraków: Wydawnictwo św. Stanisława B.M. Archidiecezji Krakowskiej, 1997), nr 18; por. konst. Sacrosanctum Concilium, 1. 12-13. Benedykt XVI na audiencji do uczestników sesji plenarnej Papieskiej Komisji ds. Ameryki Łacińskiej mówił o pobożności ludowej m. in.: „Na pobożność ludową składają się liczne formy wyrażania wiary, związane z wielkimi uroczystościami roku liturgicznego. W nich to przejawia się miłość prostego ludu Ameryki Łacińskiej do Jezusa Chrystusa, w którym znajduje objawienie bliskości Boga, Jego litości i miłosierdzia". Pobożność ludowa i nowa ewangelizacja. Do uczestników sesji plenarnej Papieskiej Komisji ds. Ameryki Łacińskiej (08.04.2011), (nr 4), choć podczas tej wypowiedzi przestrzegał też przed jej wypaczeniami: „Nie można jednak zaprzeczyć, że istnieją pewne wypaczone formy religijności ludowej, które zamiast pobudzać do aktywnego udziału w życiu Kościoła, powodują zamieszanie i mogą sprzyjać czysto zewnętrznym praktykom religijnym, nie mającym wiele wspólnego z wewnętrznie ugruntowaną i żywą wiarą. W tym kontekście chciałbym przypomnieć tutaj to, co napisałem w zeszłym roku w liście do seminarzystów: «W pobożności ludowej są elementy irracjonalne, czasem może nawet pewna powierzchowność. Jednak odrzucanie jej jest całkowicie błędne. Dzięki niej wiara zagościła w sercach ludzi, przeniknęła do ich uczuć, zwyczajów, wspólnego sposobu odczuwania i życia. Dlatego pobożność ludowa jest wielkim dziedzictwem Kościoła. Wiara stała się ciałem i krwią. Oczywiście pobożność ludowa musi wciąż być oczyszczana, połączona z centrum, ale zasługuje na naszą miłość, bo sprawia, że my sami stajemy się w całkowicie rzeczywisty sposób ludem Bożym»" (List do seminarzystów, 18 października $2010 \mathrm{r}$., $\mathrm{nr}$ 4); tamże, $\mathrm{nr} 5$, dostęp: 17.01.2020, https://opoka.org.pl/biblioteka/W/WP/benedykt_xvi/przemowienia/komlac_0804201
} 
zwyczajów i obrzędów praktykowanych w pobożności i tradycji ludowej. Celem opracowania jest nie tylko charakterystyka, ale także zwrócenie uwagi na przemiany zachodzące w społeczeństwie polskim w przeżywaniu tego dnia. W opracowaniu powyższego zagadnienia wykorzystano literaturę przedmiotu oraz własne stacjonarne etnograficzne badania terenowe prowadzone przez autora $\mathrm{w}$ subregionie opoczyńskim i radomskim nad obrzędowością doroczną (lata 1990-1994) oraz funeralną (lata 1997-2006). Ponadto autor w ostatnich latach prowadził eksploracje za pomocą metody obserwacji uczestniczącej, biorąc udział w niektórych praktykach charakterystycznych dla tego dnia podczas wykonywania funkcji liturgicznych w kościele. Oprócz etnograficznych badań terenowych, korzystał również z metody nauk teologicznych, analizy i krytyki piśmiennictwa, metody fenomenologicznej oraz porównawczej, szczególnie przydatnej w sytuacji odwoływania się do innych regionów Polski podczas charakterystyki obyczajów praktykowanych tego dnia.

W części pierwszej zostanie przedstawiona geneza liturgii Środy Popielcowej i związane $\mathrm{z}$ nią obrzędy religijne, a w drugiej sposób przeżywania tego dnia w tradycji ludowej.

\section{POPIELEC W LITURGII KOŚCIOŁA I RELIGIJNOŚCI LUDOWEJ}

W Kościele katolickim Środa Popielcowa rozpoczyna czterdziestodniowy post, który jest czasem przygotowującym na Święta Wielkanocne. Dawniej w Polsce ten dzień nazywano Wstępną Środą (dlatego że jest „wstępem” do postu i wielkanocnych uroczystości) albo Popielcem. Symboliczne posypanie głowy popiołem to znak pokuty. Obrzęd znany jest w wielu tradycjach. Wzmianki o nim znajdziemy w Starym Testamencie, gdzie obrazuje to, co przemijające i pozbawione wartości. Popiół staje się wyraźnym znakiem sytuacji, w których człowiek doświadcza własnych życiowych ograniczeń i swej bezradności wobec śmierci. Podczas modlitwy błagalnej czy też czyniąc pokutę, posypywano sobie głowę popiołem, bądź siadano lub tarzano się w popiele ${ }^{6}$. Posypanie popiołem głowy (czy całego ciała), jak i tarzanie się po ziemi było u ludów pierwotnych oznaką żałoby i żalu. W celach apotropeicznych obsypywano się popiołem lub składano ofiary za zmarłego z grudką ziemi z jego grobu.

\footnotetext{
${ }^{6}$ Zob. „Wstał więc z tronu, zdjął ze siebie płaszcz, oblókł się w wór i siadł na popiele” (Hi 3,6); „Głośno lamentują nad sobą, podnoszą gorzkie wołanie, posypują głowy ziemią i tarzają się w popiele" (Ez 27,30); por. Jan PERszon, Na Jastra, Wielki Post i okres wielkanocny w Wejherowskiem (Luzino, 1992), 6-7.
} 
W społecznościach pierwotnych, gdzie nie odczuwano lęku przed zmarłymi, starano się utrzymywać kontakt z przodkami m.in. poprzez „wszczepienie sobie" popiołu ze spalonych zwłok, aby posiąść zawartą w nim moc ${ }^{7}$.

Popiół w tradycji żydowsko-chrześcijańskiej ma przypominać o przemijaniu i ułomności ludzkiego życia, oznacza żałobę i ból. Ale nie tylko. Popiół jest także znakiem oczyszczenia i zmartwychwstania, bo Bóg stworzył człowieka z prochu ziemi i odrodził go w Chrystusie do nowego życia. W tajemnicę przemijania i wieczności wprowadza wszystkich wierzących liturgia Środy Popielcowej. W tym dniu w kościołach podczas nabożeństw posypuje się głowy wiernych popiołem, który pochodzi ze spalonych ubiegłorocznych palm wielkanocnych. W Kościele powszechnym rytuał posypywania głów popiołem wprowadzono około IV wieku, obowiązywał wówczas osoby odprawiające publicznie pokutę. Po obrzędzie posypania popiołem i nałożeniu szat pokutnych, penitenci opuszczali kościół. Mogli do niego powrócić dopiero po wielkanocnej spowiedzi w Wielki Czwartek, który uznawano za dzień odpuszczenia grzechów i pojednania z Kościołem. Od X wieku rozpowszechniono zwyczaj posypywania popiołem wszystkich wiernych, a papież Urban II na synodzie w Benewencie (1091) wprowadził go jako obowiązujący w całym Kościele. Od czasu, kiedy zwyczaj posypywania głów popiołem stał się praktyką powszechną dla wszystkich wiernych, przybrał charakter bardziej duchowy i powoli zanikało jego znaczenie jako ordo penitentium ${ }^{8}$.

W Popielec w kościele można było spotkać parafian wszystkich stanów. O ważności i powszechności tego obrzędu pisał ks. Jędrzej Kitowicz:

Na ten Popielec zjeżdżali się i schodzili do kościołów wszyscy katolickiego wy-
znania, panowie nawet najwięksi nigdy go nie opuszczali. Ale że nie wszyscy byli
sposobni w Wstępną Środę do przyjęcia tego obrządku, przeto dawano go drugi
raz po kościołach, mianowicie po wsiach, w pierwszą niedzielę postu. Taka zaś

${ }^{7}$ W Syrii żałobnicy udawali się na wysypiska poza granice miasta, gdzie wysypywano popiół z ognisk domowych, aby ochronić się przed duchem zmarłego znajdującym się w domu żałoby. Rzymianie w święta oczyszczania rzucali popiół poza siebie w wodę i w ten sposób okazywali szacunek bogom i zmarłym. U Hindusów nacierano popiołem całe ciało. W Meksyku posypywanie się popiołem miało zapewnić oczyszczenie duszy. Dorothe ForSTNER, Świat symboliki chrześcijańskiej (Warszawa: Instytut Wydawniczy „Pax”, 1990), 77-78. Jako znak żałoby nacierano popiołem całe ciało w prowincji Sepik Wschodni w Papui Nowej Gwinei. Obserwacja własna.

${ }^{8}$ Erwin MATEJA, „Popielec”, w Encyklopedia katolicka, t. XV (Lublin: Towarzystwo Naukowe Katolickiego Uniwersytetu Lubelskiego, 2001), 1417; Barbara OGRODOwsKa, Polskie zwyczaje i obrzędy doroczne (Warszawa: Sport i Turystyka Muza SA, 2009), 110; Barbara OgrodowsKA, Witaj dniu uroczysty. Wielkanoc w Polsce. Tradycja, obrzędy i zwyczaje (Warszawa: Verbinum, 2007), 20; Zdzisław KUPISIŃSKI, Wielki post $i$ Wielkanoc w regionie opoczyńskim. Studium religijności ludowej (Warszawa: Verbinum, 2000), 23. 
była jeszcze pobożność Polaków pod panowaniem Augusta III w latach początkowych, że nawet chorzy, nie mogący dla słabości przyjąć Popielcu w kościele, prosili o niego, aby im był dany w łóżku?

Jeszcze na przełomie XIX i XX wieku, gdy nie wymagano obecności wszystkich członków rodziny w kościele, księża posypywali głowę zwykle naj ważniejszej osobie, np. ojcu lub dziadkowi. Sypali także trochę popiołu do modlitewnika, a przedstawiciel rodziny obecny na mszy rozdawał go pozostałym domownikom po powrocie z kościoła ${ }^{10}$. Wśród mieszkańców Półwyspu Helskiego istniał zwyczaj nie tylko przynoszenia w modlitewniku popiołu dla chorych, ale nawet dodawania im odrobiny do napoju ${ }^{11}$. Zwyczaj posypywania głów popiołem trwa do dziś. W tym dniu w liturgii mszy św., pomimo że nie jest to dzień wolny od pracy, wierni uczestniczą licznie. Obrzęd błogosławieństwa popiołu i posypywania nim wiernych zastępuje akt pokuty. Kapłan zwraca się do zgromadzonych słowami:

Drodzy bracia i siostry, pokornie błagajmy Boga Ojca, aby pobłogosławił ten popiół, który nakładamy na nasze głowy na znak pokuty.

Po krótkiej modlitwie w milczeniu kapłan wypowiada słowa:

Panie Boże, Ty przebaczasz ludziom, którzy się upokarzają i starają się zadośćuczynić za grzechy, wysłuchaj łaskawie nasze prośby i udziel hojnie błogosławieństwa + swoim sługom i służebnicom, którzy będą posypani tym popiołem, niech wytrwają w czterdziestodniowej pokucie, aby mogli z oczyszczonymi duszami uczestniczyć w paschalnym misterium Twojego Syna. Który żyje i króluje na wieki wieków. W. Amen ${ }^{12}$.

Uczestnicy liturgii klękają przed ołtarzem, a kapłan, posypując głowy popiołem (w niektórych parafiach czyniąc popiołem znak krzyża na czole), wypowiada słowa: „Nawracajcie się i wierzcie w Ewangelię” (Mk 1,15), albo: „Pamiętaj, że jesteś prochem i w proch się obrócisz" (por. Rdz 3,19) ${ }^{13}$.

\footnotetext{
${ }^{9}$ Jędrzej Kitowicz, Opis obyczajów za panowania Augusta III, wyd. 2 (Wrocław: Wydawnictwo Zakładu Narodowego im. Ossolińskich, 1951), 553.

${ }^{10}$ KUPISIŃSKI, Wielki post $i$ Wielkanoc, 23; OGRODOWSKA, Witaj dniu uroczysty, 20-21; Jan S. Bystroń, Dzieje obyczajów w dawnej Polsce. Wiek XVI-XVIII, t. 2 (Warszawa: Trzaska, Evert i Michalski, 1960), 51; Zygmunt Gloger, Rok Polski w życiu, tradycji i pieśni (Warszawa: Jan Fiszer, 1900), 125-126.

${ }^{11}$ Jan PERSZON, Jastrë na Helu (Lublin-Jastarnia: Urząd Miasta i Gminy Jastarnia, 1994), 18-19.

${ }^{12}$ Mszat rzymski dla diecezji polskich, wyd. 2 (Poznań: Pallottinum, 2013), 62.

${ }^{13}$ Ibidem, 63; zob. też Zbigniew KuCHOwICZ, Obyczaje staropolskie XVII-XVIII wiek (Łódź: Wydawnictwo Łódzkie, 1975), 396.
} 
Symbolika popiołu zachowała pierwotne znaczenie. Środa Popielcowa pokazuje cykliczność roku liturgicznego i ludzkiej ziemskiej egzystencji. W życiu człowieka bywają okresy radości, zadumy, a także cierpienia i refleksji. Po życiowych bolesnych doświadczeniach, jeśli przeżywało się je z Chrystusem, następuje radość zwycięstwa. Liturgiczny obrzęd posypania głów popiołem ukazuje stan ,uniżenia” i pokory człowieka względem Boga, ale jednocześnie jest wyrazem dojrzałej postawy wierzącego. W Popielec wierzący uświadamia sobie swą kruchość, przygodność, przemijalność, a podjęta refleksja nad teraźniejszością, życiem i śmiercią zachęca do pracy nad sobą, aby duchowo przygotować się na święta zmartwychwstania Chrystusa. Do tej metanoi przekonują słowa modlitwy, wypowiadane przez kapłana nad popiołem, kiedy prosi Boga o błogosławieństwo dla wiernych, aby wytrwali w czterdziestodniowej pokucie i z oczyszczonymi duszami uczestniczyli w wielkanocnym misterium ${ }^{14}$.

Do wewnętrznej pracy nad sobą i pełnienia czynów miłosierdzia zachęca także Katechizm Kościoła Katolickiego, gdzie czytamy:

Podobnie jak u Proroków, wezwanie Jezusa do nawrócenia i pokuty nie ma na celu najpierw czynów zewnętrznych, »wora pokutnego i popiołu«, postów i umartwień, lecz nawrócenie serca, pokutę wewnętrzną. Bez niej czyny pokutne pozostają bezowocne i kłamliwe. Przeciwnie, nawrócenie wewnętrzne skłania do wyrażenia tej postawy przez znaki widzialne, gesty i czyny pokutne ${ }^{15}$.

Gorliwa realizacja pokuty i zobowiązanie podjęcia się dodatkowej pracy nad sobą w okresie postu (praktyki ascetyczne) jest w pewnym stopniu zadośćuczynieniem za popełnione dotychczas grzechy, a przede wszystkim stanowi rodzaj walki z własnym egoizmem, wadami, jest także próbą dostrzeżenia drugiego człowieka, będącego w potrzebie. Do tej refleksji nad sobą skłania także wszystkich wierzących obowiązujący w Środę Popielcową post jakościowy i ilościowy. Post jakościowy obliguje do wstrzemięźliwości od pokarmów mięsnych, a ilościowy - do spożycia w ciągu dnia tylko trzech posiłków, w tym jednego do syta ${ }^{16}$.

\footnotetext{
${ }^{14}$ KuPISIŃSKI, Wielki post $i$ Wielkanoc, 24; BYSTROŃ, Dzieje obyczajów w dawnej Polsce, 51; Zofia KossaK, Rok polski. Obyczaj $i$ wiara, wyd. 3 (Warszawa: Instytut Wydawniczy „Pax”, 1974), 40-41; Ewa FERENC-SzYdeŁKOWA, Rok kościelny a polskie tradycje (Poznań: Księgarnia św. Wojciecha, 1988), 112.

${ }^{15}$ Katechizm Kościoła Katolickiego, wydanie II poprawione (Poznań: Pallottinum, 2012), nr 1430.

${ }^{16}$ Zob. kan. 1251 oraz: „Prawem o wstrzemięźliwości są związane osoby, które ukończyły czternasty rok życia, prawem zaś o poście są związane wszystkie osoby pełnoletnie, aż do rozpoczęcia sześćdziesiątego roku życia. Duszpasterze oraz rodzice winni zatroszczyć się o to, ażeby również ci, którzy z racji młodszego wieku nie związani jeszcze prawem postu i wstrzemięźliwości, byli
} 
Wstępna Środa rozpoczynała czas ciszy, skupienia i wyrzeczeń, o tym mówią górale z Podhala: „Popielcowa Środa to tak jak Wielki Piątek. Myli garnki z tego tłuscu, bo jakby zjod trochę thuscu, to grzech był okropny. Ziemniaki w łupinach nasuli do sabaśnika i piekli. Jedli je z kapustą kisoną, ale nie telo kiebyś kcioł, nie do syta, bo był post. Na wiecór upiekli moskalicka z owsianej mąki. Bez cały post sie ogranicali. Muzyki? - Niech Bóg broni! Ani nikt nie zaśpiewał, ani nie zagrał” (MC 1915) ${ }^{17}$; „We wstępną środę nie wolno było ani szyć, ani prząść, ani robić ze lnu, ani z owczą wełną" (B 1904) ${ }^{18}$.

Mieszkańcy wsi zachowywali wstrzemięźliwość od potraw mięsnych, a nawet od nabiału, nie tylko w Popielec, ale i w pozostałe dni Wielkiego Postu. Starsi respondenci wspominają, że w ostatni zapustny wieczór czyszczono garnki i tygielki z wszelkich tłuszczów. Naczynia szorowano popiołem lub grochowinami oraz wypalano albo wyparzano pokrzywą, miętą lub lubczykiem i chowano do pieca, który służył do wypiekania chleba, bądź wynoszono na strych. W Wejherowskiem tak oczyszczone naczynia wynoszono na dwór i zawieszano spodem do góry na płocie, w tym dniu spożywano „pulki” (ziemniaki w mundurkach) ze śledziem, chleb suchy lub z marmoladą, czarną kawę zbożową, a wieczorem gęstą kaszę na mleku. Mieszkańcy Międzyrzecczyzny jadali czarny żytni chleb, kartofle ze śledziem i kiszonym ogórkiem, kapustę kraszoną olejem, placki kartoflane smażone na oleju z surową cebulą oraz barszcz z ćwikłowych buraków z cebulą ${ }^{19}$. Na Górnym Śląsku w Środę Popielcową posiłek spożywano tylko raz dziennie. Nie wolno było pić mleka, wyjątek czyniono jedynie dla dzieci. W czasie postu konsumowano: żur z knulami, krupy pogańskie, zupę knulową, jagły, gorzką kawę zbożową, chleb, olej roślinny, kapustę wraz z kwasem, karpiele gotowane, polewkę z suszonych owoców. Niektóre gospodynie, chcąc uniknąć pokusy przygotowania bogatszych potraw, zostawiały sobie w kuchni tylko kilka garnków niezbędnych do przyrządzenia postnego jedzenia ${ }^{20}$.

Postny charakter rozpoczynającego się okresu dostrzec można było nie tylko w skromnych posiłkach, ale również w strojach noszonych przez mieszkańców

wprowadzeni w autentyczny duch pokuty" (kan. 1252). Kodeks prawa kanonicznego, tł. ks. Edward Sztafrowski, red. Kazimierz Dynarski SAC (Poznań: Pallottinum, 1984).

${ }^{17}$ Krystyna KwaŚniewicz, „Zwyczaje doroczne”, w Podhale. Tradycja we wspótczesnej kulturze wsi, red. Danuta Tylkowa (Warszawa: Instytut Antropologii i Etnologii PAN, 2000), 365.

${ }^{18}$ Ibidem.

${ }^{19}$ Perszon, Na Jastra, 7-8; Feliks Olesiejuk, Zwyczaje i obrzędy ludu Międzyrzecczyzny (Drelów: Urząd Gminy w Drelowie, 2000), 21. Takie mycie naczyń kuchennych praktykowano także w innych regionach Polski: na Śląsku, por. Jerzy PośPIECH, Zwyczaje i obrzędy doroczne na Śląsk (Opole: Instytut Śląski w Opolu, 1987), 151.

${ }^{20}$ PoŚPIECH, Zwyczaje i obrzędy doroczne na Ślasku, 151. 
wsi. W tym czasie przeważały ubiory o barwach ciemnych, a nawet czarnych, mające wywołać wrażenie biednych, skromnych. Ciemny kolor przypominał pokutny charakter okresu oraz religijną motywację kształtującą codzienne życie mieszkańców wsi. Tak surowy post obowiązywał zarówno starszych, jak i młodszych, a przestrzegano go jeszcze na początku XX wieku ${ }^{21}$.

$\mathrm{Z}$ dawniejszych form przeżywania postu pozostało niewiele. Restrykcyjne praktyki pokutne zostały złagodzone, a post ścisły obowiązuje tylko w Środę Popielcową i Wielki Piątek. W Popielec wierni powstrzymują się od potraw mięsnych, ale spożywają nabiał oraz inne produkty żywnościowe. Nie zwracają też uwagi na kolorystykę odzieży tego dnia, ubiór zakładany na nabożeństwa w kościele nie różni się od stroju zakładanego do pracy czy szkoły.

\section{W OBRZĘDOWOŚCI LUDOWEJ}

Popielec jest uroczystością kościelną, ale Środa Popielcowa stanowi datę graniczną między kończącym się karnawałem a okresem Wielkiego Postu. Wpływ Kościoła na życie mieszkańców wsi sprawił, że do północy trzeba było zakończyć wszelkie ostatkowe zabawy i ludowe obrzędy o rozrywkowym charakterze. Wiele $\mathrm{z}$ nich nawiązywało do dawnych przedchrześcijańskich obrzędów wiosennych, a ich praktykowanie miało przynieść utylitarne konsekwencje (obrzędy agrarne i oczyszczające). Dlatego w Środę Popielcową ścierały się ze sobą dwa nurty: rozrywkowo-zwyczajowy i religijno-ascetyczny. O praktykowanych niegdyś w tym dniu zwyczajach pisze Jędrzej Kitowicz:

\footnotetext{
Po wielkich miastach w Wstępną Środę czeladź jakiego cechu, poubierawszy się za dziadów i Cyganów, a jednego z między siebie ustroiwszy za niedźwiedzia, czarnym kożuchem, futrem na wierzch wywróconym, okrytego i około nóg czysto jak niedźwiedź poobwiązywanego, wodzili od domu do domu różnych figlów z nim dokazując, którymi grosze i trunki z pospólstwa, chciwego na takie widoki, wyłudzali. Inni znowu, spory kloc do łańcucha przyprawiwszy, chwytali dziewki służebne; złapaną wprzęgali do pomienionego kloca, przymuszając do ciągnienia poty od domu do domu, poki nie złapali dla uwolnienia pierwszej ${ }^{22}$.
}

Społeczności wiejskiej, jeszcze do połowy minionego wieku, trudno było zaakceptować stan bezżenny młodzieńca czy panny. Młodzież, która osiągnęła wiek odpowiedni do małżeństwa, a nie weszła w ten związek w zakończonym karnawale, była ośmieszana nie tylko podczas zabawy ostatkowej,

\footnotetext{
${ }^{21}$ KUPISIŃSKI, Wielki post $i$ Wielkanoc, 28-29.

${ }^{22}$ Kitowicz, Opis obyczajów za panowania Augusta III, 551.
} 
ale i w Popielec. Najpowszechniejszym ze zwyczajów występujących w tym dniu była „kłoda popielcowa”. Mężczyźni zaprzęgali niezamężne niewiasty do drewnianych kłód. Zazwyczaj przetaczano przez wieś kloc drewna i przywiązywano do niego dziewczynę. Musiała ona zaciągnąć kloc do gospody i dopiero tam się wykupić, aby osiągnąć zwolnienie. W Opoczyńskiem powszechnym zwyczajem było przypinanie przez chłopców na plecach panien wchodzących do kościoła kurzych nóżek, indyczych szyjek, skorupek od jajek czy przedmiotów z drewna zwanych klockami. Kawalerowie robili to tak sprytnie, że zwykle dziewczyna nie była tego świadoma. Idąc przez kościół, wzbudzała salwy śmiechu wśród zgromadzonych wiernych ${ }^{23}$.

Pod koniec XIX wieku w wielu wsiach Międzyrzecczyzny w Środę Popielcową praktykowano pierwsze obrzędowe wyprowadzanie z osiedli ludzkich „Śmierci”, utożsamianej z „Zimą”. Po obrzędowym „utopieniu” lub „spaleniu” bałwana, symbolizującego „Zimę”, młodzież organizowała postną ucztę. Niewątpliwie ów zwyczaj jest reliktem dawnych słowiańskich obrzędów wiosennych $^{24}$. We wsiach bojarskich kobiety przychodziły do karczmy, „aby tam pić na urodę len, a gdy wszedł tam mężczyzna jaki, musiał im się okupić, inaczej posypywały go popiołem i goliły głowę patykiem" 25 .

W niektórych miejscowościach w Środę Popielcową organizowano „babski comber". Z racji postu posiadał on skromniejszy charakter, niż to bywało w zapusty. Młode mężatki próbowały wkupić się do babskiego cechu i przygotowywały na to wydarzenie postne potrawy: chleb, kiszoną kapustę, śledzie, a mężowie kupowali alkohol. Także w wielu śląskich miejscowościach w Popielec kontynuowano zabawy ostatkowe, a ów dzień uchodził za święto kobiet, kiedy to „mężczyźni nie mieli nic do powiedzenia”. Tam gdzie nie zorganizowano zabawy ostatkowej, podczas której młode mężatki mogły się wkupić do babskiego cechu, czyniono to w Środę Popielcową. O tym zwyczaju pisał J. Lompa: „Środą Popielcową jest pospolite święto kobiet w Górnym Śląsku, albowiem wszystkie, które w tym roku za mąż poszły, wkupować się muszą. Starsze zbierają kontrybucją i nawet przez przymus, co na pijatykę obrócone bywa"26. Zabawy organizowano nie tylko na wsi, ale i w mniejszych miastach. W miejscowościach położonych blisko Gliwic, Bytomia czy Pszczyny jeszcze na początku XX wieku zabawy o takiej samej

\footnotetext{
${ }^{23}$ BySTROŃ, Dzieje obyczajów, 52-53; KuchOwICZ, Obyczaje staropolskie, 397; KuPISIŃSKI, Wielki post $i$ Wielkanoc, 25-26.

${ }^{24}$ OLesiejuK, Zwyczaje i obrzędy ludu Międzyrzecczyzny, 22-23.

${ }^{25}$ Zob. Adolf PleszCZYŃSki, Bojarzy Międzyrzecczyzny. Studium etnograficzne (Warszawa: Księgarnia M. Arcta, 1892), 85.

${ }^{26}$ Cyt. za: PoŚPIECH, Zwyczaje i obrzędy doroczne na Śląsu, 152.
} 
funkcji organizowali świeżo ożenieni mężczyźni. W ten sposób wkupywali się w społeczność dojrzałych mężczyzn. Tych, którzy nie chcieli uczestniczyć w tym obrzędzie, sprowadzano nawet siłą ${ }^{27}$.

Występowanie combra w Popielec miało symboliczne znaczenie, do tego dnia młodzież mogła zawierać związki małżeńskie. Na ogół, po upomnieniach księży, wszelkie tego typu obrzędy starano się organizować w zapusty. Środa Popielcowa stanowiła więc granicę nie tylko zmieniających się okresów roku liturgicznego, ale i wyznacznik zwyczajów wiosennych, rodzinnych (zmiana stanu cywilnego) czy codziennego życia (czas pokuty i rezygnacja $\mathrm{z}$ zabaw $)^{28}$.

Kościołowi w Polsce trudno było całkowicie zlikwidować obrzędy i zwyczaje ludowe, które nie harmonizowały z wielkopostną liturgią, a wiązały się z ostatkowymi zabawami, zachodzącymi na Środę Popielcową. Na ścisłe wymogi postne nakładały się dawne zwyczaje i obrzędy rodzinne i wiosenne, które w przekonaniu ludu należało także wypełnić, aby zachować harmonię i porządek w rodzinie i społeczności wiejskiej, a przez to zapewnić sobie i najbliższym pomyślność w domostwie i gospodarstwie. Z upływem lat na polskiej wsi i w obrzędowości ludowej zachodziły znaczące przemiany, wszelkie zwyczaje i obrzędy ludowe skupione wokół Popielca z czasem zaginęły całkowicie, a pozostały jedynie te, które posiadają religijną motywację.

Środa Popielcowa rozpoczyna okres Wielkiego Postu i zachęca do poważnego, statecznego przeżywania nowego czasu liturgicznego. Tradycyjny obrzęd posypania głów popiołem dokonywany na nabożeństwie w kościele ma przypominać, że życie ziemskie mija, a silna wiara, ćwiczenia duchowe, wyrzeczenia i bezinteresowne dawanie siebie pomagają osiągnąc życie wieczne. Dobrowolne umartwienie, jałmużna, post czy choćby zwolnienie tempa własnego życia są elementami, które w szczególny sposób możemy wtedy kultywować.

\footnotetext{
${ }^{27}$ Ibidem.

${ }^{28}$ Oskar Kolberg, Dzieła wszystkie, t. 20, Radomskie, cz. 1 (Kraków: Polskie Wydawnictwo Muzyczne. Ludowa Spółdzielnia Wydawnicza, 1887), 94-95; Irena LECHOwA, „Zwyczaje i wierzenia doroczne w Łowickiem", Prace i Materiały Muzeum Archeologicznego i Etnograficznego w Lo$d z i \mathrm{nr} 11$ (1967): 32; Jan P. Dekowski, Zbigniew Hauke, Folklor regionu opoczyńskiego (Warszawa: Centralny Ośrodek Metodyki Upowszechniania Kultury, 1974), 20; Irena KuBIAK, Krzysztof KUBIAK, Chleb w tradycji ludowej (Warszawa: Ludowa Spółdzielnia Wydawnicza, 1975), 64; Joanna i Ryszard Toмiccy, Drzewo życia. Ludowa wizja świata i człowieka (Warszawa: Ludowa Spółdzielnia Wydawnicza, 1975), 173-174; KUPISIŃSKI, Wielki post i Wielkanoc, 26.
} 
Dlatego nie jest to dzień, który w sposób pobłażliwy wprowadza wierzących w czas zadumy. Popielec jest momentem podjęcia odważnej decyzji o stanowczym porzuceniu dotychczasowego grzesznego życia, niezgodnego z Ewangelią i zmianie postępowania, nawyków, co ostatecznie ma prowadzić do powrotu na ścieżkę wyznaczoną przez Chrystusa. Niegdyś w Środę Popielcową mieszkańcy wsi zobowiązywali się do rozpoczęcia surowych praktyk wielkopostnych (wstrzemięźliwość od potraw mięsnych i nabiału, rezygnacja z zabaw, umartwienie ciała i ducha) w celu właściwego przeżycia tego okresu i przygotowania się na święta Zmartwychwstania Chrystusa.

Ze względu na to, że Popielec stanowił wyraźną granicę przejścia do nowego modelu życia, wplotły się w ten dzień dawne ludowe rytuały przejścia podkreślające wejście i przyjęcie świeżo poślubionych osób do szacownego grona mężatek i żonatych mężczyzn. Kościołowi w Polsce trudno było całkowicie zlikwidować obrzędy i zwyczaje ludowe, które nie harmonizowały z wielkopostną liturgią, a które wiązały się z ostatkowymi zabawami, zachodzącymi na Środę Popielcową.

Przemiany społeczno-gospodarcze i kulturowe, a także przeobrażenia dokonujące się $\mathrm{w}$ edukacji religijnej sprawiły, że zwyczaje ludowe związane z obrzędowością matrymonialną i wiosenną zaginęły, a pozostały jedynie te, które zostały włączone w liturgię Kościoła katolickiego. Charakterystyczny zwyczaj posypywania głowy popiołem aktualny jest do dziś i symbolizuje wezwanie do wewnętrznego nawrócenia i refleksji nad dotychczasowym życiem. Stanowi także znak oczyszczenia zmierzającego do odrodzenia i osobistego zmartwychwstania, czego konsekwencją ma być odpowiednie przygotowanie na zbliżające się święta Zmartwychwstania Pańskiego. Tradycyjny obrzęd ma za zadanie przypomnieć, że życie ziemskie mija, a silna wiara, ćwiczenia duchowe, dobrowolne wyrzeczenia i bezinteresowne dawanie siebie samego drugiemu człowiekowi pomagają osiągnąc życie wieczne.

\section{BIBLIOGRAFIA}

Bystroń, Jan Stanisław. Dzieje obyczajów w dawnej Polsce. Wiek XVI-XVIII. T. II. Warszawa: Trzaska, Evert i Michalski, 1960.

DYLus, Aniela. „Pobożność”. W Stownik teologiczny, red. Andrzej Zuberbier, 417-418. Katowice: Księgarnia św. Jacka, 1998.

FERENC-SZYDEŁKOWA, Ewa. Rok kościelny a polskie tradycje. Poznań: Księgarnia św. Wojciecha, 1988. FORSTNER, Dorothe. Świat symboliki chrześcijańskiej. Warszawa: Instytut Wydawniczy „Pax”, 1990.

Gloger, Zygmunt. Rok Polski w życiu, tradycji i pieśni. Warszawa: Jan Fiszer, 1900. 
JAN PAWEt II. „Adhortacja apostolska 'Catechesi tradendae'”. W Adhortacje apostolskie Ojca Świętego Jana Pawła II. Kraków: Wydawnictwo Znak, 1996.

JAN PAWEŁ II. „List apostolski 'Vicesimus quintus annus' z okazji XXV rocznicy ogłoszenia Konstytucji Soborowej o Liturgii Świętej (04.12.1988)". W Wybór listów Ojca Świętego Jana Pawła II, red. Piotr Słabek, Jacek Jękot, 142-160. Kraków: Wydawnictwo św. Stanisława B.M. Archidiecezji Krakowskiej, 1997.

Katechizm Kościoła Katolickiego. Wydanie II poprawione. Poznań: Pallottinum, 2012.

Kitowicz, Jędrzej. Opis obyczajów za panowania Augusta III. Wrocław: Wydawnictwo Zakładu Narodowego im. Ossolińskich, 1951.

Kolberg, Oskar. Dzieła wszystkie, t. XX: Radomskie, cz. 1. Kraków: Polskie Wydawnictwo Muzyczne. Ludowa Spółdzielnia Wydawnicza, 1887.

Kongregacja ds. Kultu Bożego i Dyscypliny Sakramentów. Dyrektorium o pobożności ludowej i liturgii. Zasady i wskazania. Poznań: Pallottinum, 2003.

KossaK, Zofia. Rok polski. Obyczaj i wiara. Warszawa: Instytut Wydawniczy „Pax”, 1974.

KubiaK, Irena, KubiaK, Krzysztof. Chleb w tradycji ludowej. Warszawa: Ludowa Spółdzielnia Wydawnicza, 1975.

KuchowICZ, Zbigniew. Obyczaje staropolskie XVII-XVIII wiek. Łódź: Wydawnictwo Łódzkie, 1975.

KuPISIŃski, Zdzisław. Adwent i Boże Narodzenie w regionie opoczyńskim. Studium religijności ludowej. Warszawa: Verbinum, 1997.

KUPISIŃSKI, Zdzisław. Wielki post $i$ Wielkanoc $w$ regionie opoczyńskim. Studium religijności ludowej. Warszawa: Verbinum, 2000.

KwAŚNIEwICZ, Krystyna. „Zwyczaje doroczne”. W Podhale. Tradycja we współczesnej kulturze wsi, red. Danuta Tylkowa, 349-384. Warszawa: Instytut Antropologii i Etnologii PAN, 2000.

Kodeks Prawa Kanonicznego. Tłumaczenie ks. Edward Sztafrowski, red. Kazimierz Dynarski SAC. Poznań: Pallottinum, 1984.

„Konstytucja o Liturgii Świętej 'Sacrosanctum Concilium”.' W Sobór Watykański II, Konstytucje, dekrety, deklaracje, nr 58. Poznań: Pallottinum, 2002.

Lechowa, Irena. „Zwyczaje i wierzenia doroczne w Łowickiem”. Prace i Materiały Muzeum Archeologicznego i Etnograficznego w Lodzi nr 11 (1967): 11-51.

MateJA, Erwin. „Popielec”. W Encyklopedia katolicka, t. XV, 1417. Lublin: Towarzystwo Naukowe Katolickiego Uniwersytetu Lubelskiego, 2001.

Mszat rzymski dla diecezji polskich. Wyd. 2. Poznań: Pallottinum, 2013.

Ogrodowska, Barbara. Polskie zwyczaje i obrzędy doroczne. Warszawa: Sport i Turystyka Muza SA, 2009

OgRodowsKa, Barbara. Witaj dniu uroczysty. Wielkanoc w Polsce. Tradycja, obrzędy i zwyczaje. Warszawa: Verbinum, 2007.

OlesIEJUK, Feliks. Zwyczaje i obrzędy ludu Międzyrzecczyzny. Drelów: Urząd Gminy w Drelowie, 2000.

Perszon, Jan. Jastrë na Helu. Lublin-Jastarnia: Urząd Miasta i Gminy Jastarnia, 1994.

Perszon, Jan. Na Jastra, Wielki Post i okres wielkanocny w Wejherowskiem. Luzino, 1992.

Pleszczyński, Adolf. Bojarzy Międzyrzecczyzny. Studium etnograficzne. Warszawa: Księgarnia M. Arcta, 1892.

PoŚPIECH, Jerzy. Zwyczaje i obrzędy doroczne na Śląsku. Opole: Instytut Śląski w Opolu, 1987. 
Skotnicki, Jerzy. „Pobożność”. W Katolicyzm A-Z, red. Zbigniew Pawlak, 307-308. Poznań: Księgarnia św. Wojciecha, 1982.

TомісcY, Joanna i Ryszard. Drzewo życia. Ludowa wizja świata i człowieka. Warszawa: Ludowa Spółdzielnia Wydawnicza, 1975.

Strony internetowe:

JAN PAWEŁ II. List do seminarzystów, 18 października 2010 r., nr 4; tamże, nr 5. Dostęp: 17.01.2020. https://opoka.org.pl/biblioteka/W/WP/benedykt_xvi/przemowienia/komlac_0804201

\section{ŚRODA POPIELCOWA W LITURGII KOŚCIOŁA I OBRZĘDOWOŚCI LUDOWEJ TRADYCJA A WSPÓŁCZESNOŚĆ}

\section{Streszczenie}

Tematem artykułu jest prezentacja Środy Popielcowej w liturgii Kościoła oraz analiza sposobu przeżywania tego dnia w tradycji i pobożności ludowej, ze szczególnym uwzględnieniem zwyczajów i obrzędów. Autor, odwołując się do dokumentów Kościoła, zwraca uwagę na wartości płynące z połączenia dwóch form kultu, jakimi są liturgia i pobożność ludowa. W opracowaniu zagadnienia autor korzystał z literatury przedmiotu, a także prowadzonych przez siebie w subregionach opoczyńskim i radomskim stacjonarnych etnograficznych badań terenowych nad obrzędowością doroczną (lata 1990-1994) oraz funeralną (lata 1997-2006), w ostatnich latach posługiwał się również metodą obserwacji uczestniczącej.

Artykuł podzielony został na dwie części - w pierwszej autor przywołuje genezę liturgii Środy Popielcowej i historię towarzyszących jej obrzędów religijnych, charakteryzuje symbolikę popiołu (i jego obecność w praktykach pokutnych różnych tradycji), koncentrując się przede wszystkim na zwyczajach panujących niegdyś na polskiej wsi - uczestnictwo w liturgii, charakterystyczne postne posiłki, pokutny ubiór. Część druga opracowania ukazuje Środę Popielcową jako datę graniczną pomiędzy okresem karnawału i Wielkiego Postu, niegdyś był to bowiem dzień praktykowania ludowych obrzędów o rozrywkowym charakterze (np. „kłoda popielcowa” czy „babski comber”). Wiele z nich nawiązywało do dawnych przedchrześcijańskich obrzędów wiosennych, a ich kultywowanie miało na celu utylitarne korzyści. Autor ukazuje przemiany, jakie zaszły i wciąż zachodzą w polskim społeczeństwie w percepcji pierwszego dnia Wielkiego Postu. Podkreśla wymarcie wielu popularnych kiedyś obrzędów, wskazując również na aktualność i żywotność zwyczaju posypywania głów popiołem, który wciąż najpełniej oddaje przekaz Środy Popielcowej.

Słowa kluczowe: popiół; Środa Popielcowa; praktyki pokutne; post; pobożność ludowa. 